\title{
Discussion.
}

The Author. The AUTHOR exhibited a number of lantern-slides illustrating the subject of the Paper.

The Chairman. The Charrman, in moving a vote of thanks to the Author, remarked that the members would probably agree that it was one of the most important Papers that had ever been read in the Institution ; important not only on account of the valuable engineering information it gave, but also because it dealt with one of the greatest subjects that would have to be considered in the near future. It was well known that Canada would be one of the main sources from which the United Kingdom would derive its wheatsupply, and any facilities for the handling of the grain on its journey from the West to the ports on the East and for its transportation from Canada to this country were of immense value both to Canada and to Great Britain.

Mr. Corner. Mr. Charles Corner observed that the occasion appeared to him to be not so much one for criticism of the Paper as for discussion of the broader issues of the subject. He had no remarks to offer on the details of the construction and development of the port of Montreal, but wished to say a word or two on the principle underlying the whole of the work done there. It was clear that the general idea of recent improvements to the port of Montreal was to give deep water so near the grain-fields of Canada that no possible competition could finally divert the traffic through the United States. The Author showed that Montreal received only about 60 million bushels of grain annually, as against 100 million bushels transported through and to the United States, and it would appear that transportation by rail in the United States was effected over a longer distance at a competitive cost; the whole effect, therefore, up to the moment of the grain reaching the harbour of Montreal hy the Canadian railways, was not to give absolute power of dealing with the traffic beyond competition. In 1897 he happened to be the Engineer of the Railway Commission of Texas, and the question of the shipment of maize and cotton between the ports of St. Louis and New Orleans was brought before the Inter-State Commission at St. Louis. Nearly all of the Western and Southern States were represented there, and the traflic was competed for by the ports of 
the Atlantic coast and those of the Gulf of Mexico. The endeavour Mr. Corner. was to find out precisely the principle which the Author had embodied in his Paper, namely, what was the actual influence of facilities for transportation by water on the conveyance of agricultural products. In that case the river in question was the Mississippi, and carriage was effected by barges towed from St. Louis to New Orleans. The rate at which freight could be carried to New Orleans was about $\$ 3$ per 1,000 ton-miles, a figure which was very close to those mentioned in the Paper. But although the Mississippi river set the pace in controlling the rates, the traffic was carried by the railways, and the vast improvements carried out on the Mississippi river had simply resulted in reducing the railway rates below the competitive power of water transportation. Therefore he wished to ask the Author whether, in these days of articulated compound engines, the flattening of gradients, and the increase of the weight of railway-trains in the United States, especially compared with 20 years ago, it was not a fact that the transportation portion of the cost of wheat was unduly high, and whether the St. Lawrence, open to navigation for only 7 months of the year, was able to compete with a really efficient all-rail route to the Canadian Atlantic ports which were open all the year round. The British South Africa Company and the Rhodesian railways charged $2 s .9 d$. for transporting a bag of maize from the interior of Rhodesia and shipping it about 6,000 miles to Great Britain. That 2s. $9 d$. represented, not 33 per cent., but about 25 per cent. of the value; and not only was the percentage less but it was less on a product of less value than wheat, and the distance was much greater. Very little, if any, profit was made on the traffic, but it was dealt with under considerable difficulties - on a 3-foot 6-inch gauge and with very primitive appliances, instead of the splendid appliances and fine structures described in the Paper. So that, in view of the expenditure, and in view of the fact of the St. Lawrence being closed for 4 months in the year, it would be interesting to know which was really the natural route, and what should be the cost of hauling, handling, and selling a bushel of wheat, from Saskatoon to Liverpool. He was of opinion that 33 cents was exorbitant. It was true that a few cents extra might be some protection to the British farmer, but engineers were concerned with doing the work in the cheapest possible way. The Author had shown the magnificent work that had been done and the enormous improvement that had been brought about in Montreal Harbour, but the root question remained: which was the natural and proper route by which Canadian grain, and incidentally tho 
Mr. Corner. food-supply of Great Britain, could be brought to the people concerned ? 1

Mr. Wentworth-Shcilds.

Mr. F. E. Wentworth-Sheilds thought everyone would agree with the Chairman as to the importance of the Paper, and it was a matter for congratulation that in all the romantic history of the harbour of Montreal so many of those connected with it, including the Author, had been members of The Institution. One of the chief things that had struck him about the work at Montreal was the very low cost at which it had been carried out. Some of the work had been remarkably cheap. The only work which struck him as not being so cheap was the dredging, the cost of which, in English money, was given as about $7 d$. to $15 d$. per cubic yard. In comparison with other similar work which had been carried out at the port that seemed rather high. He noticed that the dipper dredger, which was not much seen in England, but which was very much favoured across the Atlantic, was used, and he was inclined to wonder whether the high cost was due to the use of that dredger, and whether better economy could not have been obtained with a ladder dredger. As one of the photographs had shown a ladder

1 The following notes appended by the speaker to the report of his remirks are printed at his request. - SEc. Inst. C.E.

(1) According to The Times (8 April, 1914) the Railway Commission in Canada has ordered the reduction of Western Canadian railway rates.

(2) In a dispateh to The Times dated Toronto, 14 April, it is suggested that before undertaking the construction of the Georgian Bay Canal it would be wise to see what would be the result of cheapening railway freight rates between east and west.

The Chairman of the Quebec Board emphasizes the fact that "the railway is good all the year round."

Mr. Cowie also depreates the pushing of the larger Georgian Bay scheme, but on quite other grounds.

(3) The Report of the (Canadian) Department of Trade and Contmerce for the year 1912, published in 1913, dealing with the facilities existing then, states on p. 135 as follows :-

"Notwithstanding these efforts the situation is not satisfactory . . Freight rates by lake and sea have been unusually high this year."

(4) The Commercial Review of the season ending 29 November, 1913, showing the export trade from Montreal, to which Mr. Cowie contributed admirable data as to the improvement of the port, shows at p. 147 et scq. the very great fluctuations in ocean grain freights from Montreal during last season-a good one as to ice conditions and the number of vessels offering.

$$
\begin{aligned}
& \text { Liverpool . . . . . . . . . 1s. } 9 d \text {. to } 3 \text { s. } 3 d \text {. } \\
& \text { Avonmouth . . . . . . . . . 1s. 9d. "3s. } 9 d \text {. } \\
& \text { Belfast. . . . . . . . . . . } 28.7 \frac{1}{2} d . " 3 \mathrm{s.} 4 \frac{1}{2} d \text {, }
\end{aligned}
$$

To French ports they were more stable at a higher average.

In 1912 the variation to Liverpool was $1 s$. $6 d$. to $4 \mathrm{~s}, 3 d$, 
dredger, he gathered that the Author had had experience of both Mr. Wenttypes, and perhaps he could give some interesting figures as to the comparative cost of them. With regard to the cost of the work generally, the Author mentioned that the quays built up to 1909 , which had a total length of 22,600 feet, cost about 18 million dollars, which worked out at about $£ 160$ per lineal foot of quay, including all equipment. That was a figure hard to beat in a first-class dock. Taking harbours all over the world, a thoroughly modern dock might run to quite double that figure, including the cost of equipment, and probably it would be difficult to find a harbour capable of accommodating vessels drawing 30 feet which had been built with all its equipment for $£ 160$ per lineal foot. That low cost was largely due to two things. In the first place, the Montreal Harbour Commissioners had not been at the cost of providing any graving-docks or dry docks. From the description given he gathered that there was only one such dock, and that had been built by an independent company. Upon that fact he thought the Montreal Commissioners were to be heartily congratulated. English barbour commissioners generally looked upon graving-docks or dry docks as necessary evils; they were very expensive, but they had to be provided. Most dock-engineers would bear him out when he said that they were not profitable things in themselves; they had to be provided, and the endeavour was to lose as little as possible on them. But it was remarkable that a large port like Montreal should have only one dry dock. It would be thought that it would be necessary for the working of the port to have a good many more. Probably what happened was that ocean steamers were dry-docked in Great Britain. A far more striking reason for the very economical work which had been carried out was undoubtedly the low cost of the quay-wall-about $£ 50$ per lineal foot, which, for a wall 60 feet in height, was unique. The method of construction was cheap and apparently very successful. The fact that timber could be used so largely, owing to its having a long life, no doubt accounted for the fact of the cost being so low. If an endeavour were made to use timber in that way in most English harbours, or in the harbours of any other country, it would be found that the life of the timber was so short that it would not pay; but in the fresh water of Montreal it seemed to be entirely successful. It was almost a matter of some surprise that the wall should be stable, having regard to the fact that it had so shallow a foundation, the base of the crib being only $2 \frac{1}{2}$ feet below the final dredging level. That pointed to the fact that the soil on which it was founded was exceedingly good. If such a wall 
Mr. Went- were built on a slippery clay, like, for instance, that at Southampton, worth-sheilds. it would undoubtedly slide forward: under those conditions the dimensions would have to be very considerably increased to make that type of wall sufficiently stable, and consequently the cost would be greater. He did not know whether the Author had ever amused himself in calculating the stability of a wall of such a character, but if he had, it certainly would be of value to hear the results, because both the foundation and the backing must be unusually good. $\mathrm{He}$ would be glad to hear what size of ship the Author had in view when he designed the works. It was stated in the Paper that the shipchannel was being deepened to give a minimum depth of 35 feet, or even more, but in another part of the Paper the view was expressed that the branch docks ought to be laid out so that they would accommodate a ship of 75 feet beam. Those two figures did not seem to be quite consistent. Cargo-vessels drawing 35 feet would probably have a beam of more than 75 feet; the "Olympic," for instance, which drew $35 \frac{1}{2}$ feet, had a beam of 92 feet, and although she was not a cargo-boat it was probable that cargo-vessels of the future drawing 34 feet to 35 feet would be of considerably wider beam than 75 feet.

Mr.Jacobs. Mr. Charles M. Jacobs considered that The Institution was indebted to the Author for arousing interest with regard to the Dominion of Canada and its chief port, Montreal. The competition between the seaports of the world was becoming yearly more intense, and the economic handling of railway and sea freight was a matter of vital importance in the race for supremacy. As the Author referred several times to competition between Canada and the United States it might not be out of place to draw attention to the railway freight-rate changes under consideration between the two countries. The trend appeared to be in favour of the farmer and consumer in Canada, as compared with the States. The Canadian Railroad Commission, after long consideration, had just decided there should be a substantial reduction in the rates for districts west of the Great Lakes, a reduction which had been asked for by the Boards of Trade, the Farmers' Association, and other organizations. On the other side of the border, the American railways were petitioning the Inter-State Commerce Commission for an increase of rates. The American railways now showed a heavy increase in working-expenses due to adverse legislation, increase of labour-costs, and construction of great terminals, etc., and consequently a large decrease in revenue. As an example of the enormous traffic over some of the United States railways, he had observed in this year's annual statement issued by the Pennsyl- 
vania Railroad that the total freight carried on all their lines $\mathrm{Mr}$. Jacous. owned, operated, or controlled east and west of Pittsburg and Erie amounted to 504,860,706 tons. The President of the railroad, Mr. Samuel Rea, M. Inst. C.E., in his report to the shareholders, said that, at the present time, a ton of freight was moved in the eastern territory more than 3 miles for 2 cents, and that it was the cheapest railroad service to be found on the face of the globe. It would appear that that was going a little too far, and that the charges were not calculated to give a fair return. The transportation problem in Canada appeared to be about to undergo a remarkable change in the near future by the opening of the Panama Canal, which would have a particular bearing on the western portion of Canada, because European ports would be brought 6,000 miles nearer and Vancouver would become a seaport of very great importance. It had been stated in The Times quite recently that, owing to the shallow water between Montreal and Quebec, two new Allan liners would use Quebec as a terminal port until the Government provided a 35-foot channel. That indicated that in order to keep abreast of the increase in the size and draught of new ships there was some necessity for immediate action in deepening the waterway. While realizing that it was a difficult engineering problem, he was confident that unless it was dealt with Montreal would suffer seriously. The progress of Montreal was of special interest, and from a personal inspection he could endorse the Author's statement that facilities for the storage and handling of grain in Montreal were now equal, if not superior, to those in any other port of the world; but the Author should draw the serious attention of the Harbour Commissioners to the necessity for a further advance. Certainly what was sufficient for to-day would not be sufficient for to-morrow, and there were indications of that in the Paper, where the Author said that frequently during the summer the grain-elevators worked to their full capacity. The cultivated land was extending rapidly, and there was also a rapid increase of population. In Montreal the increase in the population was creating congestion in street-travel, and an entirely new system of subways was being considered. From estimates made recently, if the increase of the population continued in the same ratio as it had done in the 5 years 1907 to 1912, the population would amount in the year 1925 to $1,450,000$, and if it increased in the ratio of the 2 years 1910-12 it would reach 1,720,000. He thought it of great importance that the attention of The Institution should be drawn more frequently to the engineering progress of the Dominion. It was a matter for 
Mr. Jacobs. congratulation that the senior Honorary Member of The Institution, H.R.H. the Duke of Connaught, was now Governor-General, and was taking the deepest interest in all matters appertaining to the progress and development of the country.

Mr. Mejk. Mr. C. S. MeIK remarked that the Paper appeared to be divisible under two heads, first, the transportation problem in Canada, and secondly, Montreal Harbour. With regard to the first, the Author struck the keynote at the beginning of his Paper, where he stated that one-third of the price paid by the British consumer for wheat represented the cost of transportation, handling, and selling. The correct solution of the transportation problem was through carriage by water, reducing the cost of transportation to Liverpool or Glasgow to the minimum. Mr. Meik did not agree with the statement of the writer in the Queen's Quarterly whose article was quoted by the Author, and he thought that many other members of The Institution would also disagree. For navigation on the Great Lakes the vessel should be in every way as strong as a vessel used on the ocean, having regard to the fact that very severe storms were at times met with on those lakes. If carriage was cheaper it could only be because the Canadians drove their steamers harder, as they could not possibly build them more cheaply than steamers were built in England. But, after all, that question was not very important, as the cost of lake-navigation represented only a very small part of the total cost between Port Arthur and Liverpool. According to the Author's figures, the rate from Port Arthur to Georgian Bay was 1 cent per bushel, or 1s. 8d. per ton, while the total rate from Port Arthur to Liverpool was 15 cents per bushel, or 25s. per ton. Through carriage would eliminate the handling and incidentals and also reduce the cost of carriage, but evidently it would not be to the advantage of Montreal, because the steamers would probably only touch there and Montreal would lose the handling of the cargo. The Author stated that in the St. Lawrence ship-channel there was practically now 30 feet of water, and 35 feet was aimed at. The Welland Canal which the Canadian Government were making was also to have 30 feet, and possibly 35 feet. The Georgian Bay Canal, with reference to which a Paper had been read before the Royal Society of Arts recently ${ }^{1}$ by Sir Robert W. Perks, was only to have 22 feet. For through carriage to Liverpool it was necessary to have 30 feet at least, and the Canadian Government apparently had that in view when they authorized the Welland Canal. There was an enormous

1 Journal of the Royal Society of Arts, vol, 1xii, p. 254 . 
traffic on the Great Lakes at the present time. In $1912 \mathrm{Mr}$. Meik. 72 million registered tons of shipping went through the Sault Ste. Marie Canal, or four times as much as went through the Suez Canal in the same year; and the bulk of the freight was destined ultimately for Europe. It would be a great advantage to the members if the Author would kindly add to the Paper another plan showing the canals of Canada referred to by him. With regard to Montreal Harbour, there was not really much to discuss in the design, but possibly the width of the jetties was open to criticism. The jetties were 340 feet, with a shed 100 feet wide, which was hardly wide enough; the shed should have been 120 feet, or even more, in width. The double-story shed helped matters, but for rapid discharge of ocean vessels it was necessary to put the whole of the cargo on the lower floor in order to sort it. In Calcutta the width at present was $\mathbf{1 2 0}$ feet, and it was proposed to increase it in future. Wherever the space could be obtained, it was the custom of dock-engineers in Great Britain to adopt a width of at least 120 feet. At Montreal the platform of the shed was higher than the quay-level and the rail-level; that was a mistake in connection with the quay, because it prevented rapid handling of goods. A quay level with the floor of the shed was conducive to great expedition in handling cargo. The Author stated that cranes were not in evidence in North American ports, and that ships' tackle, aided by electric whip winches, appeared to give more satisfaction. The crane question was a very difficult one. He had always found that wherever shipowners were given plenty of cranes they made use of them if the charge was not too high. Last year he visited three Eastern ports, Calcutta, Rangoon, and singapore. In Calcutta there were four or five cranes to a berth and they were always at work; and yet an outery had been raised that cargoes were not discharged quickly enough. At Rangoon only a limited use was made of cranes. At Singapore there was not a single crane. The extraordinary thing was that although there were three or four steamship lines having a regular service between all three ports, there was no outcry as to the want of cranes at Singapore. That showed the great difference of opinion existing as to the necessity of cranes at ports. He suggested that the cranes had not "taken on" at Montreal because they were of the transporter type, which was unsuitable for general cargoes. The best crane for that purpose was a traversing crane with a derricking jib either on the quay or on the roof of the shed; it gave greater flexibility and covered a large area of ground. With regard to the tests of the effect of the vibration of concrete during its setting, 
Mr. Meik. the results obtained were very satisfactory, but Mr. Meik would not have had the slightest doubt that that would prove to be the case. The tests showed that vibration during setting was rather advantageous than otherwise.

Mr. Wilson. Mr. Maurice F. Wirson observed that he had been taken over the works at Montreal recently by the Author, and had seen the new elevators and other improvements which were being carried out. He was not quite sure which was the more interesting part of the Paper-the introduction, or the description of the port itself. With regard to the introduction, it was quite possible to understand Canada's anxiety to retain within her own borders the transport of grain; it would be much more advantageous to her to keep it all in her own Dominions than to allow a quantity to pass through the United States. He thought the Author might have referred to one step which would tend very strongly to keep the trade in Canada, namely, the possibility of opening out Quebec as a winter port. That had been considered, and had been thought to be not at all impracticable; and it was obvious that if it were done a large portion of the grain-traffic during the winter months, when the upper part of the river was closed, would be carried down to Quebec and shipped there, instead of passing through the United States. He was informed that below Orleans Island the river was practically free from ice, and between that island and Quebec the ice could be very easily kept under by ice-breakers. He believed the Author himself was one of those who considered this to be a feasible scheme. It was stated that the depth of water in the St. Lawrence channel was 30 feet, and that it was expected it would ultimately be 35 feet, but there was a strong opinion in Canada that it was not possible to get 35 feet; in fact, the Author pointed out the difficulty when he said that the supply of water was constant, that was, of course, in the upper portion of the river above Lake St. Peter, about half way between Quebec and Montreal, which was the limit of the tide. All the upper part of the St. Lawrence had a fixed supply of water from the lakes, so that if the channel were improved it would only increase the flow and reduce the surface slope generally when the result would be to lower the depth. He had been told by several people that that had actually happened; that the summer level at Montreal had been very considerably lowered since the dredging was done, and that although the result of the dredging was a greater depth of water, the increase depth was not in proportion to the amount of dredging. In other words, dredging 1 foot did not give another foot of water, as it lowered the surface level at the same time. With regard to the 
design of the harbour itself, the Author referred to the dam between Mr. Wilson. the mainland and the island, proposed for the purpose of giving still water for a long length of the shore where the St. Mary's current now existed, and if that could be done, it would be obviously a great improvement; but the difficulty of constructing the dam in so large a volume of water travelling at high velocity would be very great. As to the depth of water to be provided in the New Welland Canal, he wondered whether it was a fact that it was proposed to give 30 feet or 35 feet; the cost of doing this would be very heavy. $\mathrm{He}$ believed there were six or seven sets of locks between the Welland Canal and Montreal, and at present the prevailing depth was about 14 feet. The cost of rebuilding the whole of those locks for 30 feet depth would be enormous, and the work would have to be continued up to the Sault locks in the upper lakes at further heavy cost. $\mathrm{He}$ was interested to find that the Author adhered to cribwork and considered that the price of timber would have to increase considerably before it was abandoned. The impression left upon him by the many opinions he had heard with regard to cribwork was that it would be far preferable, especially in well-established ports, to adopt more permanent structures. He had been told that after a time the timber in cribwork became more or less sodden and its strength diminished considerably, with the result that the pressure of the stone filling burst the crib and caused considerable dislocation of the structure. He believed the Public Works Department were in places using concrete caissons in place of cribwork. With regard to the honeycombing of the concrete, attributed to the wash of the water through the face shutters, he wondered whether the honeycombing was really due to water coming through the face, as it was much more likely that the small waves outside produced a pumping action through the rubble and sucked the cement out of the concrete below. He had seen that happen under similar circumstances, and probably the concrete was thus honeycombed to a considerable extent. With regard to the possibility of cribwork sliding, it might do so on very treacherous clay, but he did not think there would be any such danger with a wall of the size shown, and, if there were, it could be prevented by driving piles in the corners of the pockets. The Author completed his cribwork with an open bottom, only planking over certain parts for ballasting purposes. The Public Works Department, Mr. Wilson believed, planked over the whole of the bottom and made a box, and he would like to know which was the better plan. It seemed to him the open bottom would be preferable. The Author appeared to favour the practice of tying back the wall to a concrete block, but the object [THE INST, C.E. VOL. CXCVIII.] 
Mr: Wilson. of doing that was not apparent. It was far better in building a gravity wall to make it so large that it did not require to be tied, and there was plenty of room on the top of the cribwork to do that.

Mr. Liwson. Mr. A. J. LAwson could recall that almost exactly 27 years ago he saw the great ice-jam in the harbour of Montreal, in the time of the Author's predecessor, Mr. John Kennedy. The ice in Lake St. Louis had come down over the Lachine Rapids and had broken up the ice beyond the Victoria Bridge, and in a few moments the whole of this broken-up ice rushed down the St. Mary's Channel, and became jammed between St. Mary's Island, the Ile Ronde and Hochelaga, and soon the water was overflowing the quays. During the following week the food supplies of the flooded districts were carried in boats. A fortnight later he was erecting a plant for the lighting of the Lachine Canal, the first in the world to be lighted by electricity. He wished to know whether the proposed dam in the St. Mary's Channel was likely to lead to any further overflow. $\mathrm{He}$ noted that embankments had been carried along on the front and that great dock-works had been built, making rather a different Montreal from the city he knew; but if another ice-jam took place he did not think the ice-anchors above the Victoria Bridge would be of much use. If the St. Mary's Channel were blocked the jam would take place higher up, and instead of the water seeking its level lower down it would overflow above Point St. Charles. He could remember the station of the Grand Trunk Railway was under water in the great flood he had mentioned. The St. Lawrence flowed north-east, and therefore the trouble with the St. Lawrence and with Quebec was that while the ice in the west along the lakes and down to Montreal broke up early, the ice between Montreal and Quebec held for a fortnight or three weeks longer. At the time of the North-West Rebellion he was given an emergency order to light by electricity the cartridge-factory and laboratory at Quebec, so as to provide ammunition rapidly. The machinery was sent from Hamilton by the Grand Trunk Railway, over the Victoria Bridge, and down to the south-east of Quebec, instead of along the North Shore railway, and it was 3 weeks after the breaking up of the ice in the St. Lawrence at Montreal when the machinery was brought from Point Levis to Quebec over the ice. Therefore, he had been astonished to hear the last speaker mention that it was a serious consideration whether or not Quebec should be made a winter port. He had seen storms in the lakes and along the St. Lawrence, and he could not imagine anyone seriously contemplating the navigation of the St. Lawrence in the winter time when the blizzards blew over the Laurentian Mountains 
into the Gulf of St. Lawrence. One thing which might interfere Mr. Lawson. with the admirably-arranged Montreal harbour was the possibility of competition with the Grand Trunk and other railways from Winnipeg and Saskatoon, which was really the centre of the Northwest Provinces as far as grain was concerned. There was the possibility of carrying grain just as cheaply by rail, as the gradient was favourable almost the whole way. The Dominion of Canada was a very large place indeed, which had yet to be peopled, and the grain export would still increase, but 100 million bushels of wheat unfortunately still found their way by Buffalo and New York. He would like to know if the Cornwall, Beauharnois, and Lachine canals were likely to be increased to a depth which would render the work in Montreal really remunerative by enabling grain to be brought from the upper lakes to Montreal without break of bulk, because on that, much more than on the Georgian Bay canal, depended the commercial success of Montreal harbour.

Mr. C. R. S. KinkPatrick, who observed that he would confine Mr. Kirkhis remarks particularly to the handling and storage of grain, pointed out that the trade in London was entirely different from that of Montreal, the process being practically reversed. In Montreal it was chiefly ex-rail to ship; in London it was almost entirely ex-ship to rail or to barge. According to the Author, Montreal dealt with $1,100,000$ tons per annum, part of which was discharged by floating elevators and not by fixed elevators. In London about 1,850,000 tons was dealt with, and of that about $1,576,000$ tons per annum was handled by the Port Authority, 85 per cent. being discharged by floating elevators, and the remainder by hand and other means. Of the 85 per cent., $77 \frac{1}{2}$ per cent. was delivered direct to barges. The $77 \frac{1}{2}$ per cent. was discharged at a much lower rate than that quoted by the Author for London; the figure was, in fact, fabout $1 s .11 \frac{1}{2} d$, including trimming and weighing. Only a very small portion of the whole was discharged at the high rates stated in the Paper. The Author used -and rightly used for his purposes-bucket elevators, which were much cheaper to work. Mr. Kirkpatrick had the following statistics giving the relative cost of working pneumatic elevators and bhcket elevators, and the figures were interesting because it was not often that the two types of machines were worked side by side. In every case a large reduction in the engineering costs was shown in favour of the bucket elevators; but there were other things in London which favoured the pneumatic appliance, the chief of which was that London did not; get the same large masses of grain to handle that were handled in Montreal. The grain dealt with in the Port 


\section{DisCUSSION ON THE TRANSPORTATION PROBLEM [Minutes of}

Mr. Kirkpatrick,

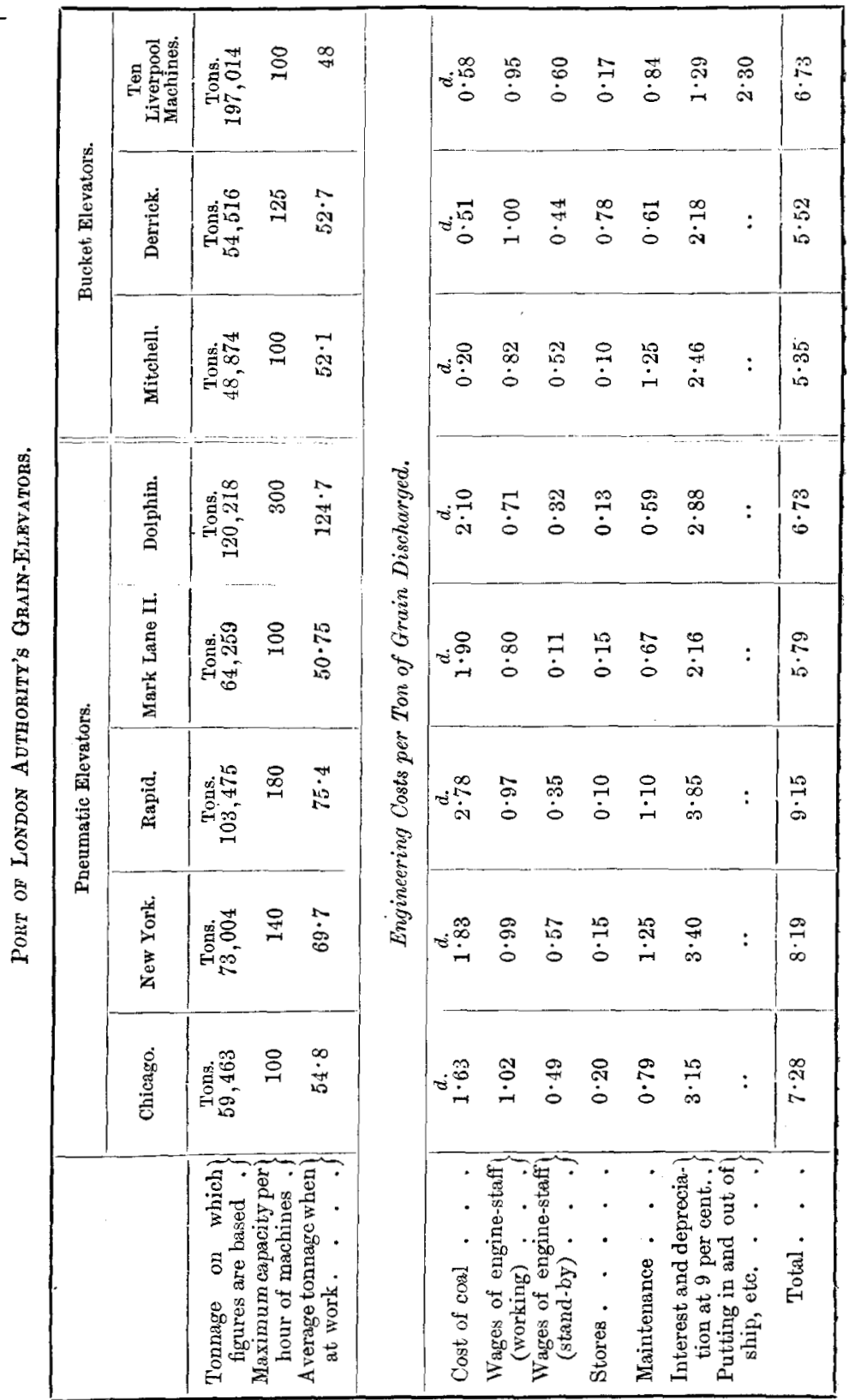


of London had to be delivered in very small parcels, and it sometimes Mr. Kirkhappened that the cargo of one ship included as many as a hundred different parcels for different merchants. The amount of clearingup work was therefore great, and it was done more cheaply by the pneumatic than by the bucket elevators. He wished to emphasize the heavy cost incurred in London in handling small parcels. Apart altogether from management and labour, the highest cost for the pneumatic elevator was $9 \cdot 15 d$. per ton, the lowest being $5 \cdot 79 d$. per ton. With the bucket elevators the lowest cost was $5 \cdot 35 d$. per ton. Having regard to the special class of work in London, some new elevators were being constructed for dealing with the work more economically than in the past. The new machines were combined pneumatic and bucket elevators, the pneumatic system being used for raising the grain out of the hold, and the bucket for elevating it. It was anticipated that those machines would reduce the cost from $5 \cdot 79 d$. to $5 d$. per ton, which would compare favourably with bucket elevators. The machines were of a new type, and were to be driven by oil-engines and turbo-exhausters. Another reason why in Montreal they could deal with grain more cheaply was that they were dealing mostly with wheat, whereas London had to deal with wheat, barley, oats and maize; and oats were more expensive than wheat to handle.

Mr. Gerald FitzGibbon congratulated the Author on the com- Mr. Fitzpression of so much valuable information into such a small space. The Paper really dealt with two subjects, either of which would have afforded sufficient material for a very long Paper and an interesting discussion. Transportation in Canada was a vast question and the figures in the ofticial returns were huge. The figures given by Mr. Meik, of the traffic passing through the Sault Ste. Marie canal, referred really to two canals-the canal in United States territory and the canal in Canadian territory; and the 72 million tons he had mentioned really represented freight tons and was not comparable with the figures for the Port of London or the Suez Canal, which represented registered net tonnage of vessels. From the latest Canadian returns the total registered tonnage through the two canals in 1913 was 58 million tons, three times the net registered tonnage in both directions through the Suez Canal for the year 1912, and twice the net registered tonnage for the Port of London for the year i913. That fact showed the enormous volume of Canadian traffic carried by water. With regard to the difficulties of transport to Montreal, the Author stated that, during the year 1913, 60 million bushels of grain were handled in Montreal and 100 million bushels of grain went through Buffalo 
Mr. Fitz- and were shipped at American ports. The rates no doubt had Gibbon. something to do with that, but at the same time one of the difficulties, if not the greatest, was the question of hauling such enormous quantities on railways; and he thought the existing Canadian railways would be quite unable to handle that quantity of grain in the time available. Calculation showed that 160 million bushels of grain would require 368 vessels, each of 12,500 tons, that was to say, of the size of the largest vessels that now navigated the Great Lakes. The same quantity of grain, conveyed in the largest box-cars used on the railways, would need a train 1,000 miles long, or 333 trains, each 3 miles in length, or practically a train 3 miles long each day throughout the whole year. He not think the Canadian railway-companies had the rolling stock to deal with such a traffic, and therefore one of the solutions of the transport problem was to construct the Georgian Bay Canal as soon as possible. Canada had been gifted by Nature with splendid waterways in the form of rivers and lakes. From Montreal to the head of the Great Lakes was roughly 1,200 miles, and from Montreal to Liverpool 2,700. $\mathrm{He}$ could not believe that if a deep waterway were made to connect the River St. Lawrence with Georgian Bay and Lake Huron-which would practically mean opening up 1,200 miles more for ocean navigation-shipowners would not construct vessels which would go right through that additional 1,200 miles and carry the grain in bulk far more cheaply than it could possibly be conveyed in any other way. He concurred with Mr. Meik in dissenting from the opinion quoted from the Queen's Quarterly. He believed that if the canal were made, ocean-going vessels would be built to pass through it. He had been connected with the Manchester ShipCanal. Before that canal was commenced it was said that it would never be made; when the first sod was cut, in November, 1887, people said it would never be finished; when it was drawing near completion they said it would never be used for steamers, but only for barges. But as soon as the canal was opened large steamers commenced to use it, special steamers being constructed, and the traffic had increased steadily. The Georgian Bay Canal was not an enormous work; the total length from Montreal to Lake Huron was 449 miles, but out of that there were only about 30 miles of artificial waterway to be constructed, and only twenty-seven locks to be made. The rest of the route was excellent river or lake navigation, only requiring improvement over a certain length.

Sir Maurice Sir MaUrice Fitzmatrice remarked that he could not lay claim Fitzmaurice to such an extensive knowledge of Canada as one of the previous speakers had, but about 25 years ago he was engaged for 3 years 
in constructing some small harbour-works on the St. Lawrence, and sir Maurice nobody could have worked on the St. Lawrence river for 3 years Fitzmaurice. without for ever afterwards taking a very keen interest in everything connected with that river. He had had occasions to pay visits to Canada every 3 or 4 years since then, and had been always much impressed, particularly in recent years, with the great strides that had been made in the improvement of the river, and the large works which had been constructed in Montreal. He was naturally more interested in the river, and would like to know how the deepening work was getting on between Quebec and Montreal, what difficulties had been met with, and whether any further great difficulty was anticipated in obtaining 35 feet of water, particularly in view of the fall in the water-level which he understood had occurred at Montreal, due to the dredging between that city and Quebec. This had been mentioned in several papers, and he had seen it stated at as much as 3 feet 6 inches. He would like also to have some further information as to the plan mentioned in the Paper of damming lakes and tributaries of the Ottawa to increase the quantity of water in the St. Lawrence at certain times of the year. Artificially increasing the depth of water in that way was a very interesting matter, and often expensive, and he would be glad to have from the Author some additions to what he said in the Paper on that subject. He would be glad, too, if the Author would add the minimum depths to the interesting Table he had given of the depths of water at Montreal during the different months of the year. In connection with some works he had been carrying out lately, Sir Maurice had been looking into the question of the tonnage per lineal foot of quay at different ports. As far as he could make out, the tonnage dealt with per foot of berth at Montreal was about 175 tons for the 8 working months of the year, which proportionally would be about 260 tons for 12 months. The Author was to be congratulated on handling so considerable a quantity per foot of berth, especially when it was remembered that grain-shipments constituted only one-fifth of the total annual freight handled. He did not think the transportation problem in Canada-the first title of the Paper-had been dealt with as fully as the second title-Montreal Harbour-but probably it would require, not a Paper at the Institution, but several volumes. It would be of value to know something, for instance, about the harbour of St John. According to the Author it was an excellent port, and grain was shipped there in winter when Montreal was closed. He would like to know whether any grain went there in summer, what the freight was from St. John to London, in 
Sir Maurice Fitzmaurice. comparison with the freight from Montreal, and what was the cost of the extra haulage between Montreal and St. John. He understood that insurance-charges were heavier on the St. Lawrence than for ports not on the St. Lawrence. He gathered from the Table (p. 107) that in the winter months the grain shipped from Halifax went round by the Intercolonial Railway, whereas it went by the short line to St. John. He did not understand why the grain for Halifax should not go the same way, except that it had to go through some of the territory of the United States; but that objection would also apply to St. John. He congratulated the Author on his good fortune in being able to obtain the money required for the works at Montreal, on the rapidity with which they had been carried out, and on their great success.

The Author. The AuтноR, in replying, remarked that the Chairman had touched the keynote of the Paper when he said that the transportation problem in Canada was one of the greatest subjects to which the ability of public men and of the members of the engineering profession could well be applied. The problem was not an easy one. The distances were very great, the population was scattered, and the physical conditions were severe. The object of the Paper was to show the rich prizes and the losses which resulted from gaining or losing transportation through Canada: it was the aim of the Paper to demonstrate that with the provision of proper facilities the Montreal and St. Lawrence route would hold its own, and would not only be the most economical one, but would be profitable directly to the whole of Canada by giving higher prices to the farmers and lower cost to the consumers. One of the keys to the situation was Montreal harbour. Buffalo harbouralso open only 7 months in the year-and the New York route could not compete economically with the port of Montreal, except when Montreal facilities had reached the limit of their capacity. As soon as Montreal was congested the trade went directly to Buffalo, which showed that Montreal was the one successful competing factor in the route. The Government of Canada and the Harbour Commissioners of Montreal had recognized the advantages to be gained, and had put forward schemes of improvement in the harbour, until at the present time it was conceded that Montreal was the best-equipped port, although not, of course, the largest, on the North American continent for vessels up to a draught of 30 feet. The end had not been reached, and could not be foreseen at the present time. It was probable that with the design and construction of important transportation routes, railways, terminals, 
elevators, lake ports, and canals, with their resulting water-powers The Author. and industries, the St. Lawrence highway would give more work to the engineer in the next few years than any other place of value in the industrial or commercial greatness of the United Kingdom. The thing which might not be justly appreciated in Canada was the urgency of construction. Six years ago he visited a great port in the United Kingdom where a new dock had been under construction for 2 years, and when he arrived recently he presumed the dock would be an old one, but on visiting it a few weeks ago he found it was still not opened. In that connection the following remarks from an engineering journal were pertinent: " The deep and spacious railway dock of Immingham is a very recent and important addition to the country's system, a new competitor amongst the ports. This great new cargo port is likely to bring home forcibly to those responsible for the port development of Hull that to procrastinate in up-to-date extensions is to stimulate the thoughts of enterprising rivals." In Canada, owing to competition and to the tremendous development of the country, 8 years was too long to wait for the construction of a single dock or even of a whole system. However, years of study and experiment and less hurried construction could not help but result in fewer failures, continued changes of design, and a nearer realization of the estimates; on the other hand, trade was lost and rivals were given an advantage, and before the construction was completed improved designs were available. As one familiar with the design and practice in the development of Canadian and American ports, and as one who had made a recent inspection of the principal European ports, and a study of some of the principal ports in the United Kingdom, he was prepared to state as his opinion that Canadian and American engineers might with advantage take more time and build more permanently; but, on the other hand, engineers in Great Britain might learn with advantage that-in some cases at least--cheaper designs would give quicker and equal results, and that there were few features in portequipment that it would be profitable to adhere to for a longer period than the life of semi-permanent structures. It was unnecessary to call attention to the organizations and facilities which were in vogue in the United Kingdom for the storage and handling of grain, as compared with similar facilities throughout a new country like Canada. In the one case there was a large population and almost limitless natural resources; in the other the people were few in number and their resources were very inadequate for 
The Author. developing their country. In each case the quantity of grain to be handled per annum was about $500,000,000$ bushels. In Canada it had been found necessary, and most remunerative, to provide the best facilities. In 1913 there were in Canada 2,333 elevators, warehouses, and milling elevators, having a total storage-capacity of $102,000,000$ bushels or $2,500,000$ tons, the whole installation representing an outlay of $60,000,000$ dollars. The tariffs and charges at the average ports in the United Kingdom, compared with those of the three chief continental North Sea ports and the port of Montreal, for equal services, convinced him that about 1 cent was lost on every bushel of grain imported into the United Kingdom. One result was that the importation of grain into continental ports was advancing by leaps and bounds, with advantage to the ports and to the capital and labour interested. In Montreal 4 years ago no wheat was exported to Germany; in the following year 1 million bushels were exported, 2 years ago 3 million bushels, and last years 6 million bushels. Mr. Corner had questioned the principles underlying the port of Montreal. One of the main objects of the Paper was to demonstrate that the port of Montreal and the St. Lawrence route could compete with the United States route. Last year the Canadian grain passing through Montreal harbour 60 million bushels as compared with 100 million bushels through Buffalo - did not represent the same proportion, having regard to the respective facilities. Buffalo had many more facilities than Montreal for both the storage and the handling of grain. With greater facilities in Montreal the proportion through the St. Lawrence would have been much larger. Mr. Corner had asked whether, in these days of compound engines, the flattening of gradients, and the increase of tonnage of railway-trains in the United States compared with 20 years ago, it was not a fact that the transportation portion of the cost of wheat was unduly high, and whether or not the St. Lawrence, open to navigation only 7 months of the year, was able to compete with an all-rail route. The Author would answer that by asking another question. Would the railway corporations of the United States build lake terminals of their own, construct and operate their own lake vessels, of enormous tonnage, for bulk freights, 7 months in the year, if they could handle the grain as cheaply on their own railways already constructed? As to the beam of ships in the future and the width of the basins, the present ships, drawing 30 feet and requiring 33 feet for navigation in a channel, had a breadth of about 68 feet, and it was anticipated that for 35 feet the breadth would be about 75 feet or more, and it was only necessary to withdraw one of the barges or, in case of very large 
ships, to enlarge one side of the basin. He would have been glad The Author. to hear a discussion on the probable results of the opening of the Panama Canal. In his opinion it would have very little effect on the carriage of Canadian products, but it would stimulate the industries on the coast, to the detriment of the interior. As to the speed of handling at Montreal, in one of the sheds illustrated in Fig. 1, Plate 5, in 1913, a vessel entered with 9,000 tons of general cargo, discharged, loaded 11,000 tons at the same berth, and sailed, in 68 hours. That was effected by the use of the ship's winches and the whip winches in the shed. With regard to the level of the shed as compared with the level of the quay, he had given that question a good deal of study. In Halifax it was a case of putting the quays level with the sheds, but in Montreal harbour, where the ships were high and the width of the quay-space in front of the sheds was narrow, the gangways projected from the ship on to the floor of the shed and the cargo was transferred without trouble. There was also room for a railway-wagon on the quay to load direct from the shed after the ship had left. With regard to the permanence of the St. Lawrence channel and the depth of water, as long as the water supplied from the Great Lakes was not tampered with or directed into any other course it was possible to rely absolutely upon the permanence of the levels of the river, and it was hoped in a very few years to have water from storagereservoirs. The question of winter navigation to Quebec was also a matter of serious importance. Notwithstanding the remarks of one speaker, the Author was perfectly clear that as soon as the transcontinental railway was constructed to Quebec, and freight was landed at Quebec in winter, ships would be built, at an extra cost of perhaps 15 per cent., which would navigate the St. Lawrence to Quebec without trouble. As they would not be passenger-ships, slight delays would not matter, and with two or three safe depots for ships to stop at in snowstorms he believed the St. Lawrence was perfectly navigable to Quebec in winter. The freight between Quebec and St. John in winter was about $\$ 3$ per ton. What ship would not risk the voyage to Quebec in winter with the addition of $\$ 3$ to its freight-rate? He had been rather disappointed that Mr. Lar:son had taken such a gloomy view of Montreal in winter and of floods in spring. There were floods in 1885 and 1886, but there had been none since. A wall had been built round Montreal which amply provided against floods in future. He was afraid Mr. Lawson had not been in Canada very lately, as he had referred to canals no longer on the map; one of them had been closed to navigation for 8 years and was now used only for water- 
The Author. power. He thought the future was much brighter than Mr. Lawson had suggested. In conclusion, he could only say he was proud as a Canadian member to have visited the Institution, and much gratified to have been received with such great courtesy.

\section{Correspondence.}

Mr. Bell. Mr. W. ReID BeLL observed that, having been connected with the preparation of the plans for the report on Montreal Harbour made in 1877 by Messrs. Bell, Newton, and Fleming, he was keenly interested in the Author's description of the progress made in the great Canadian port. It might be useful to recall some of the conditions and the views held at the time of the 1875-7 Report. The Harbour Commissioners, in their memorandum to the Reporting Commission, stated that they would

"draw . . . attention to the rapidly-increasing trade of this continent, especially of Western Canada and the Western United States. The rapidity of this increase in the last twenty-five years has made the then constructed canals in the United States and Canada utterly incompetent to meet the wants of even the present trade, hence their enlargement now, both in the United States and Canada, has become a necessity. In 1838 , only 78 bushels of grain were shipped from Chicago and Lake Michigan ; while in last year [1874], from that lake alone, the exports of cereal (without taking in provisions), were $123,000,000$ bushels. In 1846 the value of the imports and exports to and from Montreal was $\$ 10,099,180$, while last year they amounted to $\$ 65,808,448$."

The memorandum gave the following figures:--

\begin{tabular}{|c|c|c|c|c|c|c|c|c|c|}
\hline Tonna & rrivi & from sea in & $185 \frac{1}{x}$ & & & & & & Tons 72,305 \\
\hline , & $"$ & $"$ & 1874 & & & & & & , 423,423 \\
\hline , & , & from local $p$ & orts $b$ & ut not & from & & a in & 1861 & 523,224 \\
\hline$"$ & ," & " & " & $"$ & & ", & & 1874 & " 956,837 \\
\hline Reven & from & rbour dues & 1854 & . & 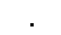 & . & . & . & . $\$ 64,000$ \\
\hline " & " & $"$ & 1874 & . & . & . & & . & $\$ 280,021$ \\
\hline
\end{tabular}

and stated that

"The St. Lawrence is ... the natural outlet for the western and south-western United States, and the Port of Montreal is 120 miles nearer to ports on the upper lakes, than any of the sea ports on this continent. The distance from Chicago or from any other lake port to Liverpool is 480 miles less via Montreal than via the Port of New York." 